\title{
STATE PRACTICE OF ASIAN COUNTRIES IN THE FIELD OF INTERNATIONAL LAW*
}

\author{
INDIA
}

\section{JUDICIAL DECISIONS $^{* *}$}

Status of refugees; Human rights; Right to equality before the law; Right to life and personal liberty; Applicability of human rights to aliens; Indian Constitution Articles 14 and 21; Indian policy of conferment of citizenship to members of the Chakma tribe

\section{Supreme Court, 9 January $1995^{1}$}

AIR 1996 SC 1234, SCALE 1996 Vol.1 p.155

\section{A.M.AhMADi CJ, S.C.SEN J \\ National Human Rights Commission v. State of ARunachal Pradesh \& ANOTHER $^{2}$}

\section{A. The case}

The case arose before the Supreme Court of India through a public interest action (class action) by the National Human Rights Commission of India (NHRC) in the form of a writ petition under Article 32 of the Indian Constitution: this Article provides a right to constitutional remedies through the Supreme Court for violations of fundamental rights. The NHRC is empowered to move the Supreme Court in appropriate cases, pursuant to Section 18 of the Human Rights Protection Act, 1993. The NHRC's allegation was that some 65,000 Chakma/Hajong tribals, settled mainly in the State of Arunachal Pradesh, were being persecuted by sections of the citizens of that State.

A large number of Chakmas had been displaced from the erstwhile East Pakistan as a result of the Kaptai Hydel Power Project in 1964. They took shelter in the nearby Indian States of Assam and Tripura and most of them later became Indian citizens. When Assam expressed its inability to bear the whole burden of the refugees, some of them who took refuge in Assam were resettled in Arunachal Pradesh (or North East Frontier Agency as it then was) after consultation with the local administration. These

\footnotetext{
* Edited by Ko Swan SIK, General Editor.

"* Contributed by V.S. MANI and GovindRAJ HEGDE, Jawaharlal Nehru University, New Delhi.

${ }^{1}$ Judgment in Writ Petition (C) No.720 of 1995.

${ }^{2}$ The second respondent was the Union of India.
}

Asian Yearbook of International Law, Volume 6 (Ko Swan Sik et al., eds.

- Kluwer Law International; printed in the Netherlands), pp. 203-232 
resettled Chakmas were about 4,012 at that time. They were allotted lands in consultation with the local tribes and also granted some financial assistance. The present population of these Chakmas in Arunachal Pradesh, after two generations, amounts to some 65,000 .

In recent years, however, thanks mainly to local politics, the relations between the original population and the Chakmas deteriorated to a point that certain sections of the former took to repressive measures against the latter. The All Arunachal Pradesh Students Union (AAPSU) called on the Chakmas to quit Arunachal Pradesh by 30 September 1995 and threatened to use force if its demand was not acceded to. Yet, in response to a communication from NHRC at the instance of a Delhi-based NGO, the People's Union of Civil Liberties, the State administration reported that the situation was totally under control.

On 15 October 1994, a Chakma NGO (the Committee for Citizenship Rights of the Chakmas - CCRC) filed a representation with NHRC complaining of the persecution of Chakmas. NHRC treated this as a formal complaint and concluded prima facie that the Arunachal Pradesh authorities were acting in coordination with AAPSU with a view to expelling the Chakmas from the State. NHRC consequently approached the Supreme Court to seek appropriate reliefs.

\section{B. The Judgment}

The Chief Justice delivered the judgment of the Court.

The Court noted at the outset that "[t]he Chakmas have been residing in Arunachal Pradesh for more than three decades, having developed close social, religious and economic ties. To uproot them at this stage would be both impractical and inhuman". ${ }^{3}$

As to the issue of conferring citizenship on the Chakmas the second respondent (the Union of India) referred to the fact that Chakma children born in Indian territory prior to $1987^{4}$ had legitimate claims to Indian citizenship. The Court's attention was also drawn by the Joint Statement issued by the Prime Ministers of India and Bangladesh in February 1972 pursuant to which the Union government had conveyed to all the States [of the Union] concerned its decision to confer citizenship on the Chakmas under Art.5(1)(a) of the Citizenship Act. ${ }^{5}$ The State government of Arunachal Pradesh, however, was found to frustrate the process by not forwarding the individual applications to the Union government authorities. ${ }^{6}$

\footnotetext{
${ }^{3}$ Para.10.

${ }^{4}$ I.e.prior to the 1987 amendment of the Citizenship Act.

${ }^{5}$ Citizenship Act (No.57) of 1955.

${ }^{6}$ The State government contended that the issue of citizenship of the Chakmas has been conclusively determined by the decision of the Supreme Court in State of Arunachal_Pradesh v. Khudiram Chakma (1994 AIR SCW 904). In the present case the Supreme Court said that this contention was 'misconceived'. See para.17. That case dealt with Chakmas who migrated to India in 1964, and who had left the lands allotted to them and had strayed out and secured land in another area by private negotiations. When the State government (of Assam) questioned the legality of the transaction and ordered them to move to the area earmarked for them, the order was challenged on the ground that Chakmas who had settled there were citizens of India, invoking Sec.6-A of the 1955 Act. This Article (made pursuant to the so-called Assam Accord) provides that all persons of Indian origin who had come to Assam before 1 Jan.1966 from territories included in Bangladesh immediately before the commencement of the Citizenship (Amendment) Act, 1985, and who had been
} 
The Court also noted the contention of the first respondent (the State government) that since the Chakmas were foreigners, they were not entitled to the protection of fundamental rights except Article 21 [of the Constitution, recognizing the right to life and personal liberty], and that, consequently, the authorities may, at any time, ask the Chakmas to move and ask the Chakmas to quit the State, if they so desire. ${ }^{7}$ The first respondent emphasized the sui generis constitutional position of Arunachal Pradesh State resulting from its ethnicity, which debarred it from permitting outsiders to be settled within its territory ${ }^{8}$, and reiterated its lack of financial resources for such contingencies. The Court found it "clear that there exists a clear and present danger to the lives and personal liberty of the Chakma".

Having rejected the first respondent's arguments the Court held:

\begin{abstract}
"We are a country governed by the Rule of Law. Our Constitution confers certain rights on every human being and certain other rights on citizens. Every person is entitled to equality before the law and equal protection of the laws. So also, no person can be deprived of his life or personal liberty except according to procedure established by law. Thus the State is bound to protect the life and liberty of every human being, he be a citizen or otherwise, and it cannot permit any body or group of persons, e.g., the AAPSU, to threaten the Chakmas to leave the State, failing which they would be forced to do so. No State Government worth the name can tolerate such threats by one group of persons to another group of persons; it is duty bound to protect the threatened group from such assaults and if it fails to do so, it will fail to perform its Constitutional as well as statutory obligations. Those giving such threats would be liable to be dealt with in accordance with law. The State Government must act impartially and carry out its legal obligations to safeguard the life, health and well-being of Chakmas residing in the State without being inhibited by the local politics. Besides, by refusing to forward their applications, the Chakmas are denied rights, Constitutional and statutory, to be considered for being registered as citizens of India." 9
\end{abstract}

Accordingly, the Court allowed the NHRC petition and ordered that the State of Arunachal Pradesh shall protect "the life and liberty of every Chakma residing within the State" and shall repel, even by use of force, any attempt by any organized group to forcibly evict the Chakmas and that "except in accordance with law, the Chakmas shall not be evicted from their homes and shall not be denied domestic life and comfort therein". ${ }^{10}$ The Court also ordered that the State "shall not evict or move the concerned persons from his occupation on the ground that he is not a citizen of India until the competent authority has taken a decision in that behalf". ${ }^{11}$

ordinarily resident in Assam since their entry into Assam shall be deemed to be citizens of India as from 1 Jan.1966. Others who had come to Assam after 1 Jan.1966 but before 25 March 1971 and had been ordinarily resident in Assam since then, could register themselves. The persons concerned in the case had claimed citizenship under this special provision, but the High Court, affirmed by the Supreme Court, held that they did not fall under the said category by having strayed away from Assam into an area within the later State of Arunachal Pradesh.

${ }^{7}$ Para. 11.

${ }^{8}$ Paras $12,14$.

${ }^{9}$ Para 20.

${ }^{10}$ Para 21(2).

${ }^{11}$ Para 21(5) 


\section{Comments ${ }^{12}$}

A few comments may be offered on this case. First, India has had its share of refugees from its neighbouring countries in different changing economic and political contexts. Its nonparticipation in the various international refugee conventions has been chiefly due to this continuing political and economic burden of refugees. Second, the present case highlights some of the problems of economic-environmental refugees, in so far as the Chakmas were originally displaced by a hydro-electric project in the erstwhile East Pakistan and it should have been the primary responsibility of the Pakistan Government to rehabilitate them. Third, having, however, played host to these hapless refugees since 1964, for about three decades, the Indian authorities (in this case, a State of the Indian Union) have a duty to protect their life and liberty, and respect their right to equality before the law and ensure equal protection of the laws. Fourth, these refugees have a right to have their citizenship applications duly considered by the Central Government and until then, a right not to be uprooted or evicted. Whether this amounts to a temporary right of non-refoulement is arguable. Finally, those fundamental rights under the Indian Constitution which apply to all persons may in appropriate cases apply to refugees. These include the right to equality before the law and equal protection of laws (Article 14), the right to protection against ex post facto law (Art. 20), the right to life and personal liberty (Article 21), the right to protection against arrest and detention in certain cases (Article 22), the right against exploitation (Articles 23 and 24), the right to freedom of conscience and religion (Article 25), the right against religious taxes (Article 26), and the right to move the Supreme Court to enforce the fundamental rights (Article 32).

From an international law point of view, the traditional rule has been that it is the sovereign right of a state to decide whether or not to admit a foreigner (including a refugee) or to grant him shelter. However, once admitted, the law of the state shall apply to the alien. The dictates of the international law on human rights, however, have now become part of the legal systems of most civilized societies. The International Covenant on Civil and Political Rights, 1966 clearly stipulates [Art. 4(2)] that certain human rights are non-derogable in any circumstances and that they include the right to life (Art. 6), the right against torture or cruel, inhuman and degrading treatment (Art. 7), the right not to be held in slavery (Art. 8), the right not to be imprisoned on the ground of inability to fulfil a contractual obligation (Art. 11), the right not to be subjected to ex post facto law (Art. 15), the right to recognition as a person before the law (Art. 16) and the right to freedom of thought, conscience and religion (Art. 18). Once admitted to the territory of a state, a refugee has, therefore, the right to expect the protection of these non-derogable basic human rights. The above decision of the Indian Supreme Court appears to endorse this international law position in so far as its application through the Indian law is concerned, although the Court did not pause to consider international law aspects as such.

\footnotetext{
${ }^{12}$ By V.S. MANI.
} 
Human rights; Right to equality before the law; Right to residence; Right to life and personal liberty; Indian Constitution Arts.14,19,21; Inter-national Covenant on Economic, Social and Cultural Rights, Art.11

\section{Supreme Court, 14 December $1994^{13}$}

1995 Supp (2) SCC 182

\section{K. Ramaswamy, S. Mohan and N.Venkatachala JJ \\ P.G. GuPTA $v$. STATE of Gujarat AND Others}

\section{A. The Case}

The Gujrat government had allotted 396 newly constructed houses to its employees on rental basis. Subsequently, the Government converted these houses from a "Lower Income Group Housing Scheme" to a "Hire Purchase Scheme". Under the converted scheme, houses would be allotted to various categories of employees fulfilling two conditions: first, continuous residence for five years; and second, not having retired from service. Later the Government passed two resolutions. The allotment of houses was sought to be given, inter alia, to certain categories of employees transferred out of the city of Ahmedabad.

This was challenged before the State High Court. The latter set aside the entitlement to this special allotment, while upholding the other criteria for other categories.

In appeal it was argued that the State government had no power under the State law to pass any resolution contrary to the statutary regulation of allotment; that allotment on priority basis defeated the rights of the weaker segments among the employees; that the criteria were irrational and arbitrary and violative of Articles 14 (equality before the law), 19(1)(e) (right to residence), and 21 (right to life and personal liberty) of the Constitution of India.

\section{B. The Judgment}

N. Venkatachala J. delivered the judgment. The Court held, inter alia:

"7. It is true that Gujarat Housing Board had constructed houses under low income group scheme for allotment to the poorer segments of the society within prescribed annual income. Article 19(1)(e) protects the right to residence and settlement in any part of the territory of India. The protection of life assured under Article 21 has been given expanded meaning of right to life. It is settled law that all the related provisions under the Constitution must be read together and given meaning of widest amplitude to cover variety of rights which go to constitute the meaningful right to life. The Preamble to the Constitution says that the people of India having resolved to secure to all its citizens social and economic justice also made it subject to equality of status and opportunity to promote the dignity of the individual in the united and integrated Bharat. Article 37 declares the rights in Part IV [as] fundamental law in the governance of the country. Article 39(b) enjoins that the owner-

\footnotetext{
${ }^{13}$ Before the Division Bench of the Supreme Court through Civil Appeal No.1529 of 1988 with Nos.1525-28 of 1988 from a judgment of the High Court of the State of Gujrat of 7 Nov.1987. With comment by GOVINDRAJ HEGDE.
} 
ship and control of the material resources of the community are to promote the welfare of the people by securing social and economic justice to the weaker sections so as to subserve the common good, to minimise the inequalities in income and endeavour to eliminate inequalities in status. The State, thereby, evolved the scheme to provide facilities and opportunities to the individuals and also groups of people who have no houses of their own. Article 46, in particular, enjoins that the State shall promote with special care the economic interest of the weaker sections of the people and ... protect them from social injustice.

8. Article 11(1) of the International Covenant on Economic, Social and Cultural Rights laid down that the States parties to the Covenant recognise the "right of everyone to an adequate standard of living for himself and for his family including food, clothing and housing and to the continuous improvement of living conditions". The States parties will take appropriate steps to ensure the realisation of these rights. Recognising these obligations of the State and [in order] to give effect to the essential importance of international co-operation [and] the directions contained in Articles 38,39 and 46, the Housing Scheme for allotment to lower income group of the people was made. Possession of real property is the basis for and the symbol of wealth and influence in society. To the poor, settlement with a fixed abode and right to residence guaranteed by Article 19(1)(e) remain more a teasing illusion unless the State provides them the means to have food, clothing and shelter so as to make their life meaningful and worth living with dignity."

The Supreme Court rejected the appeal on the ground that the State's housing allotment was flawed in the face of the law on human rights.

\section{Comments}

[See the comments under the next case.]

Human rights; Universal Declaration of Human Rights 1948, Art.25; International Covenant on Economic, Social and Cultural Rights 1966, Art.7; Constitution of India, Art.14

Supreme Court, 10 May $1995^{14}$

AIR 1995 SC 1811

K.RAMASWAMY AND N. VENKATACHALA JJ

LIFE INSURANCE CORPORATION OF INDIA AND ANOTHER (appellants) V. CONSUMER EDUCATION \& RESEARCH CENTRE AND OTHERS (respondents)

\section{A. The Case}

Life Insurance Corporation of India (LIC) had turned down proposals for housing insurance as presented by insurance agents on behalf of individual respondents. LIC

\footnotetext{
${ }^{14}$ Through civil appeal No.7711 of 1995 and cross-appeal No. 5651 of 1995, on a Division Bench decision by the High Court of the State of Gujrat, of 31 January 1994.
} 
imposed conditions which were assailed as arbitrary, discriminatory, and violative of Articles 14, 19(1)(g) and Article 21 (right to life) of the Constitution.

The High Court of Gujrat declared a part of the conditions, namely, “. . . [P]roposals for assurance under the plan will be entertained only from persons in Government or Quasi Government organisation or a reputed commercial firm which can furnish details of leave taken during the preceding year under Table 58" as violative of equality and hence unconstitutional and invalid. This decision came in for appeal and cross-appeal before the Supreme Court.

\section{B. The Judgment}

The judgment was delivered by K.RAMASWAMI J. The Court held, inter alia:

"14. From this material matrix, the question emerges whether the appellant is justified in law . . . [to] restrict the term policy only to the specified class, namely, salaried persons in Government, quasi-Government or reputed commercial firms. The Preamble, the arch of the Constitution, assures socio-economic justice to all Indian citizens in matters of equality of status and of opportunity with assurance to dignity of the individual. Article 14 provides equality before law and its equal protection. Article 19 assures freedoms with right to residence and settlement in any part of the country and Article 21 by receiving [an] expansive interpretation of [the] right to life ... to right to livelihood. Article 38 in the Chapter [on] Directive Principles enjoins the State to promote the welfare of the people by securing and protecting effective social order in which socio-economic justice shall inform all the institutions of the national life. It enjoins to eliminate inequality in status, to provide facilities and opportunities among . . . individuals and groups of the people living in any part of the country and engaged in any avocation. Article 39 assures to secure the right to livelihood, health and strength of workers, men and women and the children of tender age. The material resources of the community are required to be so distributed at best to subserve the common good. Social security has been assured under Article 41 and Article 47 [which] impose a positive duty on the State to raise the standard of living and to improve public health.

15. Article 25 of the Universal Declaration of Human Rights envisages that every one has the right to [a] standard of living adequate for the health and well-being of himself and of his family including food, clothing, housing and medical care and necessary social services and the right to security in the event of unemployment, sickness, disability, widowhood, old age or other lack of livelihood in the circumstances beyond his control. Article 7 of the International Covenant on Economic and Social Rights equally assures [the] right [of] everyone to the enjoyment of just and favourable conditions of work which ensures not only adequate remuneration and fair wages but also decent living to the workers for themselves and their families in accordance with the provisions of the Covenant. [The] Covenant on [the] Right to development enjoins the State to provide facilities and opportunities to make rights a reality and truism, so as to make these rights meaningful." 15

\section{Comments ${ }^{16}$}

The International Covenant on Economic, Social and Cultural Rights, 1966 and the Universal Declaration of Human Rights are often referred to by the Indian Courts when called

\footnotetext{
${ }^{15}$ Paras. 14-15.

${ }^{16}$ By Govindraj Hegde.
} 
upon to interpret constitutional and other statutory provisions. In P.G. Gupta's case the Supreme Court of India encountered no intricate legal issues. The Court had to determine simply whether the State High Court was justified in disentitling certain categories of Government employees for the allotment of houses on a special scheme. But in an oblique way this question had a bearing on the interpretation of the rights guaranteed under the Indian Constitution, particularly the right to reside and settle in any part of the territory of India under Article 19(1)(e). The unique point to note here was the willingness of the Court to mention Article 11(1) of the International Covenant, although it was never raised by the appellant. For its decision, the Court relied upon its two earlier cases, namely, Olga Tellis v. Bombay Municipal Corporation ${ }^{17}$ and Shantistar Builders v. Narayan Khimalal Totame. ${ }^{18}$ In the former case 'right to life' under Article 21 of the Indian Constitution was interpreted to include the 'right to livelihood'. The right to life under Article 21 was given an extended meaning in Shantistar Builders encompassing in its sweep a reasonable accommodation to live in. A reasonable accommodation does not necessarily mean adequate housing facilities, because each state's economic and social problems vary. No new propositions were offered by the Court as it had simply applied the ratio in the above two cases to P.G. Gupta's case.

The LIC of India case presents a different picture. A clause in an insurance policy restricting benefits only to the salaried class in Government, quasi-Government and reputed commercial firms was declared unconstitutional. The Court in this case recalled a number of its earlier decisions. In CESC Ltd. v. Subash Chandra Bose ${ }^{19}$ the Court had interpreted the meaning of Article 19(1)(e) of the Indian Constitution vis-à-vis Article 25(2) of the Universal Declaration of Human Rights and Article 7 of the International Covenant on Economic, Social and Cultural Rights. The Court in that case had held the right to 'social justice' as a fundamental right. Another important decision on which the Court relied was Regional Director, Employees State Insurance Corporation v. Francis De Costa ${ }^{20}$ where the Court emphasized the need to give an effective interpretation to the Indian Employees' State Insurance Act. It held that the right to medical benefit is a fundamental right. Therefore the Court in the LIC of India case struck down the conditions in the insurance policy as violative of fundamental rights guaranteed in the Indian Constitution in view of their arbitrary exclusion of other similarly placed individuals.

However, the merits of these decisions should not obscure the fact that the Supreme Court had failed to analyse properly the relevant international human rights law provisions in interpreting the provisions of the Indian Constitution. ${ }^{21}$ Instead it merely stated them and made no attempt whatsoever to analyse them. Secondly, the Court also failed to examine how 'fundamental' are the 'second generation' human rights (social, economic and cultural rights). The Court appears to take the facile course of looking at all human rights through the device of Article 21 of the Indian Constitution.

${ }^{17}$ Supreme Court Cases 1985, Vol. 3, pp. 545, 572.

${ }^{18}$ Supreme Court Cases 1990, Vol. 1, p. 520.

${ }^{19}$ Supreme Court Cases 1992, Vol. 1, p. 441.

${ }^{20}$ Supreme Court Cases 1993, Vol. 1, Supp. 4, p. 100.

${ }^{21}$ Article 2(1) of the International Covenant on Economic, Social and Cultural Rights, 1966 imposes an obligation on promotional basis "to take steps individually and through international assistance and cooperation, especially economic and technical, to the maximum of its available resources, with a view to achieving progressively the full realisation of the rights recognised in the Covenant by all appropriate means, including particularly the adoption of legislative measures". 
Despite these comments, these decisions seek to develop a universal view of human rights based on developmental stages, and project a judicial willingness to treat the international human rights instruments almost as part of the domestic human rights law.

\section{State succession; Act of State in municipal context}

\section{Supreme Court, 9 May $1995^{22}$}

1995 Supp (3) SCC 297

\section{N. VENKataChala AND KULDIP Singh JJ}

Maharaja Kumar Kharak Singh $v$. State of Punjab AND

Maharaja Kumar GuRbaX Singh $v$. STATE of PunJab AND Others

\section{A. The Case}

The case related to a farm land, 'Bir Bhadson', claimed by the appellants to have been part of the private property of the erstwhile Ruler of the Princely State of Nabha. Nabha along with seven other princely states of the Punjab signed a covenant on 5 May 1948 (which came into force on 20 August 1948) for the formation of a new state, the Patiala and East Punjab States Union (PEPSU). In 1956 the PEPSU merged with the State of Punjab, a State of the Union of India.

On 25 April 1948 the Ruler of Nabha wrote a letter to appellant GuRBaX SINGH (one of his brothers), whereby he made over the above farm land to his two brothers (appellants). GURBAX SINGH returned to India from overseas some time in November 1948 and accepted the conveyance of the farm land. The PEPSU and later the State of Punjab refused to release the land and hence the present case.

Actions for recovery of possession were initiated in 1960. The District Judge, Patiala, held that the non-recognition of the rights of the plaintiffs in regard to the grant of land covered in the above letter was an 'act of state', and hence adjudication by a municipal court upon the correctness of such an 'act of state', whether it had reference to public or private rights, was beyond its competence as a municipal court. Consequently, it dismissed the suits. The case was then taken up by the plaintiffs in 1963 before the Punjab and Haryana High Court, which agreed substantially with the findings of the District Judge. The case then came before the Supreme Court.

\section{B. The Judgment}

The judgment was delivered by VenKatachala, J.

The crux of the case was whether the land in question was part of the Nabha ruler's private property or part of the state property of the Nabha State. Neither in his letter nor in the documents relating to the covenant did the Ruler clarify if the land in question was his private property, or whether his letter to his brother amounted to its effective conveyance. The crucial point of fact was that the conveyance made by the Ruler of Nabha in favour of his brothers was accepted by the appellant only after the covenant on the state merger had come into force.

\footnotetext{
${ }^{22}$ Civil appeal No.316 of 1978, against the judgment of the Punjab and Haryana High Court of 9 March 1977.
} 
"If that be so, 'Bir' continued to be the state property of Nabha State till 5-5 1948, when [the] covenant for bringing into existence of [the] State of PEPSU was signed and further up till 20-8-1948 when the State of PEPSU actually came into existence, becomes indisputable."23

The question whether all the State properties came to vest in the State of PEPSU was answered by the Court in the affirmative. ${ }^{24}$ The Court then continued:

“16. Next question is . . . is it open to a person, who claims title to 'Bir' . . . to recover possession of the same from the successor State of PEPSU of Nabha State or the successor State of Punjab of PEPSU although it was the subjectmatter of the said covenant ...

17. [In case of] state properties of Nabha for which private parties have a claim as in the present case, can they claim . . . by filing a suit in an ordinary civil court (Municipal Court) on the plea that the sovereign Ruler . . . entering into the covenant with other sovereigns had wrongly transferred that property to the new State of PEPSU so as to vest in it?"

This question was answered by the Court in the negative on the ground of the act of state doctrine, with reference to, inter alia, Article 363(1) of the Indian Constitution. In the Court's view, the subject-matter of the case was "the subject of the covenant between sovereign Rulers of independent States".

Therefore, the appeal was dismissed.

\section{Comments ${ }^{25}$}

There were more than 500 princely states in India at the time of Independence in 1947 and they became part of the Indian Union through covenants, sanads and agreements. All questions relating to these relationships are, pursuant to Article 363 of the Indian Constitution, debarred from adjudication by the Indian judiciary. While this bar was imposed in view of the territorial integrity of India, there is no doubt that a host of legal issues are still beckoning legal researchers even after 50 years of Indian independence. ${ }^{26}$

\footnotetext{
${ }^{23}$ Para 12.

${ }^{24}$ Para.14.

${ }^{25}$ By V.S. Mani.

${ }^{26}$ A pioneering effort in this regard has been the work by T.T. POULOSE, Succession in international law: A study of India, Pakistan and Burma (New Delhi,1974).
} 


\section{INDONESIA}

\section{LEGISLATION}

Maritime territory; archipelagic waters; passage rights

Act on Indonesian Waters (Act No.6/1996 of 8 August 1996) ${ }^{27}$

Considering that ...

(c) the regulation of the archipelagic legal regime in Government Regulation in lieu of Act No.4 of 1960 on Indonesian Waters is no more in accordance with the developments of the law on archipelagic states as contained in Part IV of the [UN] Convention [on the Law of the Sea];

Decides:

ChaPTER I: GENERAL PROVISIONS

$\cdots$

\section{CHAPTER II: THE INDONESIAN WATERS}

\section{Article 3}

1. The Indonesian waters comprise the Indonesian territorial sea, the archipelagic waters and the internal waters.

2. The Indonesian territorial sea consists of a belt of sea extending to 12 nautical miles measured from the Indonesian archipelagic baselines referred to in Article 5.

3. The Indonesian archipelagic waters consist of all waters enclosed by the [situated on the inward side of the] straight archipelagic base lines regardless of their depth or distance from the coast.

4. The Indonesian internal waters consist of all waters situated on the landward side of the low-water line along the coasts of Indonesia, including all waters situated on the landward side of a closing line as referred to in Article 7.

\section{Article 4}

The sovereignty of the Republic of Indonesia over Indonesian waters extends to the territorial sea, the archipelagic waters and the internal waters and to the air space

${ }^{27}$ The Act is published in the Lembaran Negara [State Gazette for legislative instruments] 1996 No.73, and the explanatory memorandum in the Tambahan Lembaran Negara [Annex to the State Gazette] No. 3647.

Translation by the General Editor. Barring manifest intention of the legislature to deviate from the provisions of the 1982 Convention on the Law of the Sea, the text of the Convention has been followed in translating the corresponding provisions of the Act. 
over the territorial sea, the archipelagic waters and the internal waters, as well as to their seabed and subsoil including the natural resources contained therein.

\section{Article 5}

1. The archipelagic baseline is drawn by using straight archipelagic lines.

2. In case no straight archipelagic baselines as referred to in paragraph 1 can be drawn, normal baselines or straight baselines shall be used.

3. The straight archipelagic baselines referred to in paragraph 1 are straight lines joining the outermost points of the outermost islands and drying reefs of the Indonesian archipelago.

4. The length of a straight archipelagic baseline as referred to in paragraph 3 shall not exceed 100 nautical miles, except that up to 3 percent of the total number of baselines enclosing the Indonesian archipelago may exceed that length, up to a maximum length of 125 nautical miles.

5. The straight archipelagic baselines referred to in paragraph 3 shall not be drawn to and from low-tide elevations, unless lighthouses or similar installations which are permanently above sea level have been built on them or where a low-tide elevation is situated wholly or partly at a distance not exceeding the breadth of the territorial sea from the nearest island.

6. A normal baseline as referred to in paragraph 2 is the low-water line along the coast.

7. A straight baseline as referred to in paragraph 2 is a straight line joining the outermost points of a coastline which is deeply indented and cut into or of a fringe of islands along the coast in its immediate vicinity.

\section{Article 6}

1. The archipelagic baselines of Indonesia drawn in accordance with Article 5 shall be shown on charts of a scale or scales adequate for ascertaining their position. Alternatively, a list of geographical co-ordinates of points, specifying the geodetic datum may be substituted.

2. The charts of an scale or scales adequately illustrating the area of the Indonesian waters or the list of geographical co-ordinates of points of the archipelagic baselines of Indonesia as referred to in paragraph 1 shall be established by Government Regulation.

3. The Indonesian Government shall give due publicity to the charts or lists referred to in paragraph 1 and shall deposit a copy of the lists [!!] with the Secretary-General of the United Nations.

\section{Article 7}

1. The Indonesian Government may draw closing lines at the mouth of rivers, estuaries, bays, inland seas and harbours in the archipelagic waters for the delimitation of the internal waters.

2. The internal waters consist of (a) the internal sea and (b) the inland waters. 
3. The internal sea referred to in paragraph 2 item (a) is that part of the sea which is situated on the landward side of the closing line at the seaward side of the low-water line.

4. The inland waters referred to in paragraph 2 item (b) consist of all waters situated on the landward side of the low-water line except at a river mouth, where the inland waters comprise all waters situated on the landward side of the closing line of the river mouth.

\section{Article 8}

The outer limit of the Indonesian territorial sea shall be measured from the baselines drawn in accordance with the provisions of Article 5.

\section{Article 9}

1. Without prejudice to the provisions of Article 4, the Indonesian Government shall respect existing agreements and treaties with other states relating to areas falling within the archipelagic waters.

2. The terms and conditions for the exercise of the rights and activities referred to in paragraph 1 , including the nature, the extent and the areas to which they apply shall, at the request of any of the states concerned, be regulated by bilateral agreement.

3 . The rights referred to in paragraph 2 shall not be tranferred to, or shared with third states or their nationals.

4. Existing submarine telecommunication cables laid by another state or a foreign legal entity and passing through Indonesian waters without making a landfall shall be respected.

5. The Indonesian Government shall permit the maintenance and replacement of such cables upon receiving due notice of their location and the intention to repair or replace them.

\section{Article 10}

1. Where the Indonesian coast and that of another state are opposite or adjacent to each other, and failing agreement between them to the contrary, the line of delimitation between the territorial seas of Indonesia and the other state shall be the median line every point of which is equidistant from the nearest points on the baselines from which the breadth of the territorial seas of the two states is measured.

2. The provision of paragraph 1 shall not apply where it is necessary by reason of historic title or other special circumstances to delimit the territorial seas of the two states in a way which is at variance with that provision.

\section{ChAPTER III: RightS OF PASSAGE OF Foreign ShIPS}

\section{Part One: InNocent Passage}




\section{Article 11}

1. Ships of all states, whether coastal or land-locked, enjoy the right of innocent passage through the territorial sea and the archipelagic waters of Indonesia.

2. Passage means navigation through the Indonesian territorial sea and archipelagic waters for the purpose of:

(a) traversing that sea without entering internal waters or calling at a roadstead or port facility outside internal waters; or

(b) proceeding to or from internal waters or a call at such roadstead or port facility.

3. Innocent passage as referred to in paragraph (1) shall be continuous and expeditious, but includes stopping and anchoring in so far as the same are incidental to ordinary navigation or are rendered necessary by force majeure or distress or for the purpose of rendering assistance to persons, ships or aircraft in danger or distress.

\section{Article 12}

1. Passage is innocent so long as it is not prejudicial to the peace, good order or security of Indonesia, and so long as it takes place in conformity with the Convention and with other rules of international law.

2. Passage of a foreign ship shall be considered to be prejudicial to the peace, good order or security of Indonesia if in the territorial sea or in the archipelagic waters it engages in any activity prohibited by the Convention or by other rules of international law.

3. Further rules on innocent passage as referred to in paragraphs 1 and 2 shall be established by Government Regulation.

\section{Article 13}

1. The Indonesian Government may suspend temporarily in specified areas of the territorial sea and archipelagic waters the innocent passage of all kinds of foreign ships if such suspension is essential for the protection of the security of Indonesia, including weapons exercises.

2. The suspension referred to in paragraph 1 shall take effect only after having been duly published according to the applicable rules.

3. Further rules on temporary suspension as referred to in paragraphs 1 and 2 shall be established by Government Regulation.

\section{Article 14}

1. Where necessary, having regard to the safety of navigation, the Indonesian Government shall designate sea lanes and traffic separation schemes in the territorial sea and the archipelagic waters.

2. Further rules on the use of sea lanes and traffic separation schemes in the territorial sea and the archipelagic waters as referred to in paragraph 1 shall be established by Government Regulation. 


\section{Article 15}

In exercising the right of innocent passage in the territorial sea and the archipelagic waters, submarines and other underwater vehicles are required to navigate on the surface and to show their flag.

\section{Article 16}

Foreign nuclear-powered ships and ships carrying nuclear or other inherently dangerous or noxious substances shall, when exercising the right of innocent passage, carry documents and observe special precautionary measures established for such ships by international agreements.

\section{Article 17}

Further rules on the rights and duties of commercial ships, warships and government ships operated for commercial and for non-commercial purposes when exercising the right of innocent passage shall be established by Government Regulation.

\section{Part Two: Right OF ARCHIPELAgic SEA laNES PASSAGE}

\section{Article 18}

1. Archipelagic sea lanes passage in specially designated sea lanes means the exercise in accordance with the Convention of the rights of navigation and overflight in the normal mode solely for the purpose of continuous, direct, expeditious and unobstructed transit.

2. Foreign ships and aircraft of all states, whether coastal or land-locked, enjoy the right of archipelagic sea lanes passage in the Indonesian archipelagic waters between one part of the high seas or the Indonesian exclusive economic zone and another part of the high seas or the Indonesian exclusive economic zone.

3 . Further rules on the rights and duties of foreign ships and aircraft when exercising the right of archipelagic sea lanes passage as referred to in paragraphs 1 and 2 shall be established by Government Regulation.

\section{Article 19}

1. The Indonesian Government shall designate sea lanes and air routes thereabove, suitable for the exercise of the right of archipelagic sea lanes passage by foreign ships and aircraft as referred to in Article 18 and may also prescribe traffic separation schemes as referred to in Article 14 for the safe passage of ships in such sea lanes.

2. Such sea lanes and air routes as referred to in paragraph 1 shall be defined by a series of continuous axis lines from the entry points of passage routes to the exit points through the archipelagic waters and the adjacent territorial sea.

3. When circumstances require, after giving due publicity thereto, sea lanes and traffic separation schemes may be substituted by other sea lanes and traffic separation schemes. 
4. In designating or substituting sea lanes or prescribing or substituting traffic separation schemes, the Indonesian Government shall refer proposals to the competent international organization with a view to their adoption.

5. The Government shall indicate the axis of the sea lanes and the traffic separation schemes designated or prescribed by it on charts which shall be published.

6. Foreign ships conducting archipelagic sea lanes passage shall respect established sea lanes and traffic separation schemes.

7. Further rules on sea lanes and traffic separation schemes as referred to in paragraph 1 shall be established by Government Regulation.

\section{PART THREE: Right OF TRANSIT PASSAGE}

\section{Article 20}

1. All foreign ships and aircraft enjoy the freedom of navigation and overflight solely for the purpose of continuous, direct and expeditious transit of a strait through the Indonesian territorial sea between one part of the high seas or the Indonesian exclusive economic zone and another part of the high seas or the Indonesian exclusive economic zone.

2. The right of transit passage shall be exercised in accordance with the provisions of the Convention, other rules of international law and legislative regulations in force.

\section{Article 21}

1. Where necessary, having regard to the safety of navigation, the Indonesian Government may designate sea lanes and prescribe traffic separation schemes for transit passage as referred to in Article 20.

2. Further rules on sea lanes and traffic separation schemes as referred to in paragraph 1 shall be established by Government Regulation.

\section{PART Four: ACCESS AND COMMUNiCATION}

\section{Article 22}

1. If a part of the archipelagic waters of Indonesia lies between two parts of the territory of an immediately adjacent neighbouring state, Indonesia shall respect the existing rights and all other legitimate interests which that state has traditionally exercised in such waters through regulation by bilateral agreement.

2. The Indonesian Government shall respect the installation of submarine cables and shall permit the maintenance and replacement of existing cables upon receiving prior and appropriate notice. 
Chapter IV: Utilization, MANAgEMENT, ProteCtion AND ENVIRONMENTAL PRESERVATION OF THE INDONESIAN WATERS

\section{Article 23}

1. The utilization, management, protection and environmental preservation of the Indonesian waters shall take place on the basis of national legislative regulations in force and international law.

2. The administration and jurisdiction, protection and environmental preservation of the Indonesian waters shall take place on the basis of the legislative regulations in force.

3. Where necessary for an increased utilization and an improved management, protection and environmental preservation of the Indonesian waters as referred to in paragraph 1 a coordinating body may be established by Presidential Decree.

\section{CHAPTER V: UPHOLDING OF SOVEREIGNTY OND LAW ON OHE INDONESIAN WATERS}

\section{Article 24}

1. The upholding of sovereignty and the law in the Indonesian waters, the airspace thereover, the seabed and the subsoil including their natural resources as well as the sanctions against their violation shall take place in accordance with the Convention, other international law and applicable legislative regulations.

2. The exercise of jurisdiction over foreign ships traversing the territorial sea and the Indonesian archipelagic waters for the purpose of upholding sovereignty and the law shall take place in accordance with the provisions of the Convention, other international law and applicable legislative regulations.

3. Where necessary for the upholding of the law as referred to in paragraphs 1 and 2 a coordinating body may be established by Presidential Decree.

\section{CHAPTEF VI: TRANSITORY PROVISIONS}

\section{Article 25}

(1) Pending the Government Regulation as referred to in Article 6 paragraph 2, an illustrative chart of a scale or scales indicating the territory of the Indonesian waters or a list of geographical coordinates of the baselines of the Indonesian archipelago shall be annexed to this Act.

(2) The implementing regulations of the Government Regulation in lieu of Act No.4 of 1960 on the Indonesian Waters shall remain in force to the extent that they are not contrary to the present Act or not yet replaced by new implementing regulations based on the present Act. 


\section{CHAPTER VII: CONCLUDING PROVISIONS}

\section{Article 26}

With the coming into effect of this Act, the Government Regulation in lieu of Act No.4 of 1960 relating to the Indonesian Waters is abolished.

\section{JAPAN}

\section{JUDICIAL DECISIONS ${ }^{*}$}

Obligation on the part of the accused of foreign nationality to bear the expenses for the defence counsel and the interpreter; International Convention on Civil and Political Rights, Article 14(3)(d) and (f)

\section{Tokyo High Court, 3 February 1993}

\section{X $v$. STATE OF JAPAN}

$\mathrm{X}$, a Nigerian national, was found guilty of violating the Cannabis Control Law and the Customs Law at the Yokohama District Court on 5 August 1992. X appealed to the High Court which also found him guilty.

$\mathrm{X}$ asserted that it was a misapplication of the law by the Court when it obliged the accused of foreign nationality to bear the expenses for the official defence counsel and the interpreter, as it was in violation of the International Covenant on Civil and Political Rights, Article $14(3)(d)$ and $(f)^{28}$, and that the decision must, therefore, be reversed.

The Court examined the question of whether it was permitted in light of the Covenant to oblige the accused to bear the expenses for the litigation. First, with regard to the expenses defrayed to the official defence counsel, the object of Article 14(3)(d)

\footnotetext{
* Contributed by TOMIOKA MASASHI, Nagoya Economics University, Nagoya, member of the Study Group on Decisions of Japanese Courts Relating to International Law.

${ }^{28}$ The relevant provisions read as follows, in part:

"Art.14(3). In the determination of any criminal charge against him, everyone shall be entitled to the following minimum guarantees, in full equality ...

(d) To be tried in his presence, and to defend himself in person or through legal assistance of his own choosing; to be informed, if he does not have legal assistance, of this right; and to have legal assistance to him, in any case where the interests of justice so require, and without payment by him in any such case if he does not have sufficient means to pay for it; ...

(f) To have the free assistance of an interpreter if he cannot understand or speak the language used in court."
} 
of the Covenant is to prevent an accused from being tried if he is denied the assistance of defence counsel for financial reasons despite such need on his part for his defence, by appointing a defence counsel without any payment by the accused, thus guaranteeing sufficient means of defence in the process of the trial. The Court, therefore, did not find that Article 14(3)(d) prohibited obliging the accused to bear the expenses when the accused had already been found guilty and the sentence pronounced, and held for this reason that it could not support the claim of the accused, on the basis of Article 14(3)(d) of the Covenant on Civil and Political Rights, that it was not allowed to order the accused to bear the expenses for defence counsel.

Secondly, with regard to the expenses defrayed to the interpreter, the Court found that the expenses for interpretation were of a different nature than those for defence counsel in the following three respects:

(1) The right to the assistance of interpreters is provided a statutory basis by the Covenant, which has self-executing power in Japan. However, even before the Covenant was ratified, the assistance of interpreters was offered as a matter of customary practice in Japanese courts, reflecting an understanding that the assistance of interpreters for the accused constituted an indispensable element for the court proceedings.

(2) In the case of the right to assistance of defence counsel, private defence counsel and defrayment by the accused himself are the rule, while the right of the accused to the assistance of interpreters is unconditional and absolute, and consequently the principle of private defrayment of the costs shall not be applicable here.

(3) In the International Covenant on Civil and Political Rights, Article 14(3)(f) the term 'free assistance' is used, which means that the expenses are not assumed to be borne by private persons. Consequently, the assistance shall be offered free of charge regardless of the financial state of the accused.

Based on the reasoning presented above, the Court decided that, with regard to the expenses defrayed to the defence counsel, the Code of Criminal Procedure, Article 181 , stipulating that the accused may be exempted from the obligation to bear these expenses if the accused finds himself in acute financial difficulties, should be applied, and, with regard to the expenses for the interpreter, Article 14(3)(f) of the International Covenant should be applied and the litigation costs for the first and second instances should not be borne by the accused.

The right to vote in local elections for foreign nationals permanently residing in Japan; the meaning of the terms 'the people' and 'the residents' as stipulated in Article 15 paragraph 1 and Article 93 paragraph 2, respectively, of the Japanese Constitution; the meaning of the term 'the citizens' as stipulated in Article 25 of the International Covenant on Civil and Political rights; Articles 27 and 29 of the same Covenant

\section{Fukui District Court, 5 October 1994}

Hanrei Jiho [Judicial Reports] No.1535 (1995) p.77; Hanrei Taimuzu [Law Times Reports] No.881 (1995) p.76; Shomu Geppo [Monthly Bulletin of Litigations] Vol.41, No.11(1995) p.2762

X et al. $V$. State of Japan et al. 
The plaintiffs, who were nationals of the Republic of Korea and had the right of permanent residence in Japan, brought a suit against the State of Japan and the election administration

committees of the various cities and towns where the plaintiffs resided in Japan, claiming the determination of the unlawfulness of the state's behaviour by denying the plaintiffs the right to be registered in the electorate lists, and demanding a compensation for the violation of the plaintiffs' right to vote. The plaintiffs, who either were born in the former Japanese colony of Korea or were offsprings of such persons, asserted that they were entitled to the right to vote in the elections for heads and members of the assemblies of local public entities where they had their residence.

The plaintiffs' claims were mainly based on the following grounds:

(1) Article 15 paragraph 1 of the Japanese Constitution ${ }^{29}$ stipulates that 'the people' have the right to vote. "The people: here refers to all those who are under a legal obligation to obey the decisions from the public entities of which they are constituent members, and foreign nationals permanently residing in Japan are included therein.

(2) Article 93 paragraph 2 of the Constitution of $\operatorname{Japan}^{30}$ stipulates that the representatives of local public entities shall be elected by 'the residents'. 'The residents' here refers to the constituent members of local public entities, and foreign nationals oermanently residing in Japan are included therein.

(3) Article 25 of the International Covenant on Civil and Political Rights ${ }^{31}$ which prescribes the right to vote, stipulates that 'every citizen' (the expression "the people possessing the nationality" is not used) is entitled to the right to vote, which implies that the right to vote is not restricted to the people who have the nationality of the country concerned. It is, therefore, evident that under the provision foreign nationals permanently residing in the country are included in 'the citizens'.

The Court, dismissing the claim of the plaintiffs, decided as follows:

(1) 'The people' as provided in Article 15 of the Japanese Constitution refers to those who are the constituent members of the state, namely, "the persons possessing Japanese nationality". The right to vote presupposes the existence of the state and can be granted only to those people meeting some specific requirements, and, due to its unique nature, is rightfully granted only to the Japanese people and foreign nationals are, therefore, not entitled to it.

\footnotetext{
${ }^{29}$ Art.15 reads as follows, in part: "The people have the inalienable right to choose their public officials and to dismiss them".

${ }^{30}$ The relevant provision reads as follows:

"Art.93 . . . (2) The chief executive officers of all local public entities, the members of their assemblies, and such other local officials as may be determined by law shall be elected by direct popular vote within their several communities." (The italicized words are the official translation of "jumin ga chokusetsu . . . senkyosuru" which literally means "shall be elected by the direct vote of the residents")

${ }^{31}$ The relevant provisions read as follows, in part:

"Art.25. Every citizen shall have the right and the opportunity, without any of the distinctions mentioned in Article 2 and without unreasonable restrictions:

(a) to take part in the conduct of public affairs, directly or through freely chosen representatives;

(b) to vote and to be elected at genuine periodic elections which shall be by universal and equal suffrage and shall be held by secret ballot, guaranteeing the free expression of the will of the electors."
} 
(2) 'The residents' as provided in Article 93 paragraph 2 presupposes 'the people' as stipulated in Article 15 paragraph 1, and it is appropriate to interpret the term as referring to 'the residents' which are a constituent part of 'the whole people'. Consequently, the Japanese Constitution grants only those who possess the Japanese nationality the right to vote in the elections of local public entities, to which foreign nationals permanently residing in Japan are not entitled.

(3) Article 25 of the International Covenant on the Civil and Political Rights, which corresponds to Article 21 of the Universal Declaration of Human Rights, stipulates in paragraph 1that everyone "has the right to take part in the government of his country" and declares that only those who possess the nationality of the country concerned are granted the right to vote. It is evident that the term 'every citizen' as used in Article 25 of the Covenant is not intended to prohibit making the possession of the nationality of the country concerned a condition of the right to vote. The term 'citizens' refers to those who possess civil rights and should be distinguished from such terms as 'peoples' or '[every-]one'. In the International Covenant on Civil and Political Rights the term 'every citizen' is used only in Article 25 with reference to the right to vote, thus reflecting the exclusive nature of this right. Therefore, the term 'every citizen' as used in Article 25 of the International Covenant cannot be interpreted as including foreign nationals permanently residing in the country concerned.

Lastly, the Court, citing the examples of countries such as Sweden where foreign nationals are vested with the right to vote in elections for members of the assemblies of the localities where they reside permanently, found that it would not be unconstitutional to grant the right to vote in elections at local levels to foreign nationals who meet some specific requirements, and that it is a matter of legislative policy whether or not to grant such a right to foreign nationals.

\section{SINGAPORE}

\section{JUDICIAL DECISIONS ${ }^{32}$}

Arbitration; Requirements for enforcement of foreign award; public policy; comity of nations

High Court, 29 September 1995

[1996] 1 SLR 34

\section{JUDITH PRAKASH J}

RE AN ARBITRATION BETWEEN HAINAN MACHINERY IMPORT AND EXPORT CORPORATION AND DONALD \& MCARTHY PTE LTD

\footnotetext{
${ }^{32}$ Texts of the decisions contributed by Soh Tze Bian, Attorney General's Chambers, Singapore.
} 
The plaintiffs were an organization constituted under the laws of China; the defendants were an organization constituted under the laws of Singapore. The parties entered into a contract for the sale of goods by the defendants to the plaintiffs. A dispute subsequently arose which was submitted to arbitration in China by the plaintiffs, in accordance with the contract. The award was in favour of the plaintiffs. As the defendants did not satisfy the award, the plaintiffs applied for an order that they be at liberty to enforce the award as a judgment or order of the court. An order to that effect was made. The defendants then applied for the order to be set aside and for another order that the award should not be enforced against them. The application was heard by the assistant registrar and was dismissed. The defendants appealed to the High Court.

Among the arguments put forward by the defendants were the following: (a) the subject matter of the difference was not capable of settlement by arbitration under the law of Singapore since the jurisdiction conferred upon the arbitrators did not specify the law governing the contract nor the curial law of the arbitration proceedings, and under section 31(4)(a) of the International Arbitration Act 1994 (see 5 AsYIL 267) the court may refuse to enforce the enforcement of an award on such subject matter; (b) it would be contrary to the public policy of Singapore to allow the award to be enforced because the defendants had raised facts which would give rise to the possibility that the award did not decide on the real matter in dispute between the parties and an injustice would be done to the defendants if the award were to be enforced.

As to the first argument the court held that it was not in accordance with the facts. In regard to the second argument the court agreed with the plaintiffs that the argument was a back door route to inviting the court to look at the merits of the case. The 1994 Act does not provide as a ground for setting aside an award the fact that the court, hearing the application, considered that the defendants had an arguable case. The court said:

"In my view, public policy did not require that this court refuse to enforce the award obtained by the plaintiffs. There was no allegation of illegality or fraud and enforcement would therefore not be injurious to the public good. . . . [T] principle of comity of nations requires that the awards of foreign arbitration tribunals be given due deference and be enforced unless exceptional circumstances exist. As a nation which itself aspires to be an international arbitration centre, Singapore must recognise foreign awards if it expects its own awards to be recognised abroad. ...."

The appeal was dismissed. The defendants appealed to the Court of Appeals.

Habeas corpus; Extradition; Relevant considerations governing exercise of discretion by magistrate; political offence; extradition brought in conjunction with refugeeship

High Court, 22 May 1996

[1996] 2 SLR 747 


\section{RUBIN J}

\section{John Muhia Kangu $V$. Director of PRISONS}

The applicant, a police officer from Kenya, was involved in an incident in which he and his colleague had reportedly opened fire and killed two unarmed persons owing to some confusion over their identities. He fled, first to Norway, and later arrived in Singapore using his nephew's passport. He was first granted a 14-day social visit visa but was later arrested for being in possession and having used another person's passport. The authorities subsequently learned that he was wanted by Interpol Nairobi for two counts of murder and that a warrant had been issued for his arrest in Kenya, and a requisition from Kenya was received for the applicant's arrest and surrender.

The Minister for Law exercised his discretion and issued a notice under section 22(1)(a) of the Extradition Act , authorizing a district judge to issue the requisite warrant for the apprehension of the applicant provided that the provisions of the Act relating to the issue of such a warrant had, in the opinion of the district judge, been complied with. The government in its affidavit averred that the minister had no grounds to believe that the request by the Kenyan government was politically motivated. The district judge ruled that there was sufficient evidence to justify the extradition. The applicant then applied for a writ of habeas corpus.

\section{RUBIN J:}

“...

The main contention of the applicant . . . is that the charges brought against him are not made in good faith, that they contain an element of political flavour . . . and further, that he had been framed.

The matters that should weigh in the mind of the court to which an application has been made for a writ of habeas corpus are tabulated under 5.25 of the [Extradition] Act . . .

...

Besides the foregoing, there is a restriction under s.20(1) of the [Extradition] Act in relation to the surrender of persons connected with offences of a political character. Section 20(1) provides as follows:

“. . . A person shall not be liable to be surrendered to a declared Commonwealth country if the offence to which the requisition for his surrender relates is, or is by reason of the circumstances in which it is alleged to have been committed or was committed, an offence of a political character."

It is clear . . that the court hearing a habeas corpus application does not rehear the case that was before the magistrate or district court. Its function, . . . is to consider whether the applicant was lawfully detained, besides hearing any issue as to whether the offence charged is political in nature. In my opinion, the principal contention of the applicant that the charges preferred against him possessed a political flavour, is outlandish and without any substance. The offences reportedly committed were not in pursuance of any political objective and the feature that a relative of one of the victims called at the residence of a Kenyan Minister soon after the incident to relate the event, does not transform the offences referred to as being political by any yardstick, . . . 
The applicant also referred the court to the Geneva Convention, apparently to the Convention relating to the Status of Refugees signed at Geneva on 28 July 1951. Apart from the fact that Singapore is not a signatory to the said Convention, there is no evidence whatsoever to suggest that the applicant's refusal to return to Kenya was due to his fear of being persecuted for reasons of religion, nationality, membership of a particular social group or any political opinion so as to bring him within the description of 'refugee' within art.1(A) therein. At any rate art. $1 \mathrm{~F}(\mathrm{~b})$ of the Convention expressly excludes from its ambit persons such as the applicant, who are alleged to have committed serious non-political crimes outside the country of refuge prior to his admission to that country as a refugee.

It is an established principle of law that when all the evidence has been presented,the magistrate's duty is simply to enquire whether a prima facie case has been made out against the accused by credible evidence (see Chua Han Mow v. Superintendant of Pudu Prison [1979] 2 MLJ 70 adopting the principles enunciated by BeLlamy J in Re Osman Bin Abdullah [1954] MLJ 237 at p.238). In my opinion, the dispositions placed before the learned district judge amply justified his issuing the warrant of commitment; he had in no way exceeded his jurisdiction nor had he applied the wrong principles in arriving at the conclusion as he did.

... As a result, I dismissed this application ..."

Private international law; passing of property in respect to chattels; determination of lex situs

\section{Court of Appeal, 26 September 1996}

[1996] 3 SLR 377

\section{KARTHIGeSU and L.P. ThIAN JJA, LAI KeW ChAI J}

\section{DiAmond Centre Pte \& ANother $v$. R. Esmerian, InC. \& ANOTHER}

Jewellery was consigned by R.Esmerian, Inc. (RE, incorporated in New York) to Corvina Inc. (incorporated in Panama), who consigned them to Wolfers Trading AG (Swiss company), who in turn consigned them and handed them to FAKHREDDIN (Iraqi national, first defendant), all this having taken place in Geneva. Under the memorandum of consignment between WOLFERS and FAKHREDDIN the jewellery were handed to FAKHREDDIN to enable him to do a special presentation to his customers in the United Arab Emirates. They might not leave the UAE for any destination except Geneva. The jewellery were entrusted to FAKHREDDIN for 15 days only. Any item sold was to be paid for immediately and any item not paid for and not returned remained the property of WOLFERS. The memorandum was to be interpreted according to Swiss law and both parties agreed to submit to the jurisdiction of the Swiss courts. FAKHREDDIN was supposed to return the consignments by 11 November 1989, but he failed to do so or to pay for the goods. The jewellery were misappropriated by 
FAKHREDDIN who sold them in Singapore to Diamond Centre Pte Ltd. and its director, TEO (second and third defendant).

Some of the jewellery was traced and found in Diamond Centre's premises in Singapore. RE and Corvina sued the defendants for conversion, seeking the return of certain pieces of jewellery and damages. RE also sought a declaration that they were the rightful owners of the jewellery.

The second and third defendants claimed that the recovered jewellery were purchased by them in good faith from the first defendant, being a mercantile agent in possession of them with the consent of the owners. The defendants mounted an alternative defence that under Swiss law, property in the jewellery had passed to FAKHREDDIN. The court heard two expert witnesses. According to the first witness (for the plaintiffs) the memorandum of consignment was a 'commission contract', under which the commissionnaire undertakes to arrange the sale of movable property in the commissionnaire's own name, but for the account of the principal, to a third party buyer for a commission. As a result the commissionnaire acquires no title. According to the second witness (for the defendants) the memorandum was a 'consignment contract', whereby the consignor undertakes to transfer the goods at a fixed price to the consignee for the consignee to sell to a third party in the consignee's own name and for the consignee's own account. Consignment essentially being for a fixed period only, the consignee has to return the goods or pay for them at the end of the period, becoming their owner in the latter case. If the consignee does neither, the consignor can assert an ownership claim after having terminated the agreement. Until then the consignor only has a claim in contract for the price of the goods.

The trial judge found that the defendants had not shown they purchased the jewels in good faith. He found, inter alia, that the jewels were bought at a substantial undervalue and that the invoices given by the first defendant were irregular. As to the defendants' Swiss law argument, the trial judge did not appear [according to the Court of Appeals] to have made a finding that Swiss law applied, though apparently he accepted that the lex situs rule does not apply where the person claiming title has not acted bona fide, though it was not clear whether he was referring to Singapore law or Swiss law as the lex situs. As FAKHREDDIN had in fact elected to return the jewellery he could acquire no title under Swiss law and hence could not confer title on the defendants. The defendants appealed.

M. KARTHIGESU JA (delivering the judgment of the court):

“... .

We do not think that Swiss law is applicable at all. The inescapable fact was that the jewellery were in Singapore when Fakhreddin sold them to Teo. It seems to us clear beyond argument that the lex situs was Singapore law.

Swiss law is only relevant if it was shown that under Swiss law, Fakhreddin had acquired title to the goods in Switzerland, before he purported to sell them in Singapore to Teo. According to Professor Piotet's theory, which was advanced by the defendants' expert witness, a consignee acquires the property to the consigned goods in a blocking situation when he either acquires the goods, sells them to a third party, or otherwise disposes of them in breach of his obligation. Fakhreddin did none of these acts while he was in Switzerland. It was only when the seized jewellery were in Singapore that he sold them to Teo. By which time, the lex situs was Singapore law. ...." 
The appeal was dismissed.

\section{THAILAND ${ }^{33}$}

\section{LEGISLATION}

\section{Contiguous zone}

Royal Proclamation establishing the Contiguous Zone, 14 August $1995^{34}$

“...

For the purpose of exercising the rights of the Kingdom of Thailand with regard to the contiguous zone, which are based on generally recognized principles of international law, it is deemed appropriate to establish the contiguous zone of the Kingdom of Thailand as follows:

1. The contiguous zone of the Kingdom of Thailand is the area beyond and adjacent to the territorial sea of the Kingdom of Thailand, the breadth of which extends to twenty-four nautical miles measured from the baselines used for measuring the breadth of the territorial sea.

2. In the contiguous zone, the Kingdom of Thailand shall act as necessary to:

(a) prevent violation of customs, fiscal, immigration or sanitary laws and regulations, which will or may be committed within the Kingdom or its territorial sea;

(b) punish violation of the laws and regulations defined in (a), which is committed within the Kingdom or its territorial sea.

..."

\section{JUDICIAL DECISIONS}

Extradition of nationals; Sanctity of contract and good faith in the law of treaties; object and purpose of a treaty

Court of Appeal, 26 December 1995

(unpublished)

Somchai Julniti, Bancha SAHAKiatmontri, SERI Choonhatanom JJ

THE PUBLIC PROSECUTOR $V$. THANONG SIRIPRECHAPONG ${ }^{35}$

\footnotetext{
${ }^{33}$ Contributed by Kriangsak Kittichaisaree, Royal Thai Embassy, Washington D.C.

${ }^{34}$ Royal Gazette, Vol.112, Part 69 (Ngor), 29 August B.E.2538 (A.D.1995),p.1. Unofficial translation by the ministry of foreign affairs of Thailand.

${ }^{35}$ English summary made from an unofficial Thai summary provided by the Thai ministry of foreign affairs and from a transcript of the judgment as published in Thai newspapers.
} 
The US had requested the extradition of Mr. THANONG SIRIPRECHAPONG, a former Member of Parliament, to stand trial for the offence of narcotic drugs trafficking involving the importation into the US of multiple container loads of marijuana over a ten-year period between 1977-1987 in which the said person together with five or more others were involved and from which they gained a great amount of profit.

The defendant sought a motion to dismiss the extradition proceedings, arguing:(1) the prosecution could not seek a court order for his detention pending extradition since the Thai Cabinet had not resolved to extradite him;(2) the offences for which his extradition was sought were committed outside the US, but since the jurisdiction in which the alleged offences had taken place was not specified the defendant was neither punishable under US law nor under Thai law;(3) the defendant was in fact not the same person as the one sought by the US;(4) a Thai national was not extraditable under section 16 of the 1929 Extradition $\mathrm{Act}^{36} ;(5)$ the prosecution had no sufficient evidence to substantiate their allegation against the defendant. ${ }^{37}$

The Criminal Court ${ }^{38}$ on 17 July 1995 (Black Case No.1973/2538) held against the defendant and ordered his detention pending his extradition since extradition was allowed pursuant to the Thai-US Extradition Treaty of $1983^{39}$ and the Extradition Act of 1990 for the implementation of the Treaty. The defendant appealed to the Court of Appeal. $^{40}$

Regarding the question of permissibility of extradition of nationals the Court of Appeal, en banc, started its opinion by mentioning the principal Thai law on the matter, viz. the Extradition Act,B.E.2472 (1929 AD), section 4 of which reads:

"Even in the absence of an extradition treaty, the Siamese government may extradite an accused if it deems appropriate to do so, or if the offence carries a punishment in the jurisdiction of the requesting state provided that it shall also be an offence punishable by Siamese law with imprisonment of at least one year."

According to the court this provision sets out the principle that it is within the government's discretion to extradite a person if the stipulated requirements are met.

The court drew attention to exceptions to the rule, such as provided in sections 5 and 16 of the Act. Section 5 stipulates:

"A request for extradition shall not be granted if the person sought has been tried and convicted or acquitted in the requested state for the offence for which extradition is requested."

Section 16 provides:

\footnotetext{
${ }^{36} 46$ Royal Gazette 271, Part 43, of 22 Dec.B.E.2472 (A.D.1929).

${ }^{37}$ The following summary of the judgment is limited to items 1 and 4.

38 'Criminal Court' refers to the criminal court in Bangkok. Provincial courts have jurisdiction in both criminal and civil matters and are identified by the name of the provinces where they are located. The court took its decision in the following composition: Manitya Jittjantaraklub, president, Samakki Maneeratna and Jamras Srithawachpongse, members.

${ }^{39}$ Treaty of 14 Dec.1983, not yet published in the UNTS. The treaty entered into force on 17 November 1991.

${ }^{40}$ By virtue of sec. 17 of the 1929 Extradition Act the Court of Appeal is the court of final judgment in extradition cases.
} 
"If the court finds that the defendant is a Siamese subject . . . the court shall report to and consult the minister of justice before issuing a court order for the defendant to be released."

Most important, however, section 3 of the Act provides:

"This Act shall be applicable to all extradition proceedings in Siam so far as it is not inconsistent with the terms of any treaty, convention or agreement with a foreign state, or any royal proclamation issued in connection therewith."

Consequently, it was necessary to find out whether the extradition treaty between Thailand and the US of 1983 contained any term which is inconsistent with the 1929 Act.

The issue of the nationality of the requested person is dealt with in Article 8 of the Treaty:

“(1) Neither Contracting Party shall be bound to extradite its own nationals.

In a case in which the United States of America is the requested state, the executive authority shall have the power to extradite its nationals if, at its discretion, it is deemed proper to do so.

In a case in which Thailand is the requested state, the competent authority may extradite its nationals if not prevented from doing so.

(2) If extradition is not granted pursuant to paragraph 1 of this Article, the requested state shall, at the request of the requesting state, submit the case to its competent authority for prosecution. . . .

(3) Notwithstanding paragraph 2 of this Article, the requested state shall not be required to submit the case to its competent authority for prosecution if the requested state has no jurisdiction over the offence."

Article $8(1)$ thus lays down the principle that in case of the requested person being a national of the requested state, the latter is not obliged under the treaty to comply with the request for extradition. However, Article 8 also shows the intention of both contracting parties to extradite their own nationals. ${ }^{41}$ For Thailand, it appears from section 4 of the 1929 Act that the competent authority specified in the treaty is the Royal Thai government.

The intention of both contracting parties to benefit each other comported with their wish to conclude the 1983 treaty and replace the previous treaty of 30 December $1922 .{ }^{42}$ This is evident from the preamble of the 1983 treaty which reads: “. . . Desiring to provide for more effective co-operation between the two States in the suppression of crime; and Desiring to conclude a new Treaty for the reciprocal extradition of offenders; . . ."

Apparently the previous extradition treaty was not sufficiently beneficial to the parties. For example, Article 8 of the 1922 treaty provided that "each of the Contracting Parties may decide not to extradite its own nationals to the other Contracting

\footnotetext{
${ }^{41}$ The 1983 Treaty with the US which, like the one with the UK, leaves room for the extradition of Thai nationals, is an exception to the consistent practice in 27 Thai extradition treaties under which Thailand denies extradition of Thai nationals. The exceptions are borne out by the practice of the US and the UK of permitting extradition of their own nationals.

4225 LNTS 394.
} 
Party”, and Thailand later enacted the 1929 Extradition Act, section 16 of which prohibited extradition of Thai nationals. It was true that section 3 of the Act provided an exception to section 16 in case of an international agreement to the contrary, but article 8 of the 1922 Treaty was not inconsistent with section 16 of the 1929 Act. The issue for the court to decide was, consequently, whether the proviso "if not prevented from doing so" under Article 8(1) of the 1983 treaty fell within the purview of the provision of section 16 of the 1929 Act.

In the opinion of the Court of Appeal, not only the sanctity of contract but also good faith is a factor of utmost significance in treaty relations. At a time of facilitated inter-state intercourse, treaties between states and the good faith of the parties to a treaty has become even more important. This was apparent from the provisions of the Vienna Convention on the Law of Treaties of 1969, which, although Thailand was not a party, could be taken into account in deciding the present case. The court then quoted Article 31 of the Convention which contained a general rule of interpretation of treaties: "1. A treaty shall be interpreted in good faith in accordance with the ordinary meaning to be given to the terms of the treaty in their context and in the light of its object and purpose. ..."

The 1983 Treaty had as its object and purpose more effective cooperation between the two states in the suppression of crime by extending mutual cooperation. Suppose the contracting parties to the 1983 Treaty had indeed agreed to have unequal treaty obligations, with the Thai side prohibiting extradition of Thai nationals pursuant to section 16 of the 1929 Extradition Act by adhering to the principle of personal jurisdiction over Thai nationals even if they commit offences outside Thailand, while on the other hand the United States would strictly adhere to the principle of territorial jurisdiction, why then had the Thai government agreed to the provision of Article 8(1) of the 1983 Treaty, allowing the government to extradite Thai nationals in spite of the prohibition under section 16 of the 1929 Act? If Thailand had actually intended not to extradite Thai nationals, it would be useless for the Treaty to provide that Thailand had discretion to extradite Thai nationals. Instead, the Treaty would have provided that only the United States was obligated to extradite its nationals if, at its discretion, it was deemed proper to do so.

With regard to section 13 of the 1929 Extradition Act which compels the court to take account of the defendant's defence of nationality, the section would be applicable only if there were indeed a prohibition of extradition on grounds of nationality.

The next question was whether the 1983 Treaty has retroactive effect. Article 19 of the Treaty provides that it shall apply to extraditable offences committed before as well as after the date of the entry into force of the Treaty. The court emphasized that the Treaty merely stipulates extradition procedures without mandating punishment and that the imposition of punishment by the court of the requesting state is unrelated to the extradition. The period in which the defendant was alleged to have committed the offences, from 1973 to 1987 , was covered by the treaty and his extradition was, therefore, not prohibited for that reason.

The next question raised in the appeal was whether the government had in fact resolved to extradite the defendant. According to testimony of the Secretary-General of the Cabinet, an inter-agency meeting had been arranged of representatives of the 
ministries of foreign affairs and justice, the Office of the attorney-general and the Office of the Juridical Council for the formulation of a recommendation to be forwarded to the Cabinet. According to the testimony the meeting unanimously agreed that the government should decide in favour of extradition. The question of a prohibition of extradition of nationals should be left to the court to decide, but could be dealt with only after the Cabinet had resolved to extradite.

In dealing with the question the court took account of sections 8 and 9 of the 1929 Act. These provisions deal with the procedures to be followed by the government in submitting the case to the court and those to be followed by the court. The court concluded that according to these provisions extradition cases indeed come before the court only after the government has resolved in favour of extradition. The request by the public prosecutor to the court to order the detention of the defendant pending his extradition and the contents of a note sent by the Cabinet to the Attorney-General were considered by the court to be convincing evidence of the fact that the government had indeed decided for extradition.

The appeal was dismissed. 